\title{
LAND EVALUATION OF SOME AREAS OF EL-FAYOUM DEPRESSION, EGYPT USING REMOTE SENSING AND GIS TECHNIQUES
}

\author{
EL GHONAMEY, Y. K. , M. M SOLIMAN and M. M. SHOMAN
}

Soils, Water, and Environment Research Institute, ARC, Giza

(Manuscript received 19 June 2018)

\begin{abstract}
$\mathrm{T}$ he purpose of this study is to evaluate some soils in ElFayoum depression using Remote Sensing (RS) and Geographic Information System (GIS). For this purpose, twenty-five soil profiles and seventy-two minipits were described in the field and their representative samples were laboratory analyzed. Using, geological map, Digital Elevation Model (DEM) and visual interpretation of satellite data a physiographic soil map was produced to present soil mapping units of the studied area. The area under investigation was classified into four landscape units, i.e. Alluvial Plain, Lacustrine Plain, Aeolian Plain and finally lake and lagoon (13.14 \% of the total studied area). Soil taxonomic unit were identified. These soils can classified into Aridisols, Vertisols, and Entisols orders. Land capability was used to evaluate the soils of studied area. According to modified Storie Index model. The area is classified into five capability grades reflect the limitation factors. Grade 1 about $41.85 \%$ without any limiting factors, Grade 2 about $15.94 \%$ where the soil main limiting factor is soil profile depth, Grade 3 about $17.30 \%$, where soil depth of soil profile. Texture and salinity are the main limiting factors, Grade 4 about $6.91 \%$. Where the limiting factors are soil depth and salinity. Grade 5 about $4.86 \%$ represented the most area of shallow soils.

Four crops were selected to assess soil suitability for cultivation in the studied area, i.e. wheat, barley, cotton and olive. The results indicated that olive was the best crop for growing in such soils.
\end{abstract}

\section{INTRODUCTION}

Desert and uninhabited land represent approximately $95 \%$ of the total area of Egypt. Consequently, the majority of the population is concentrated around the Nile valley and in the Nile Delta. This unbalanced distribution of inhabitants causes serious social and economic problems, such as the fact that the ever-increasing population has resulted in a decrease in agricultural area per capita from 0.13 ha. in 1947 to 0.05 ha. in 2004 (FAO, 2005).

El-Fayoum Depression lies in the Western Desert of Egypt close to the Nile valley at a distance of $40 \mathrm{~km}$, it lies to the south-west of Cairo at a distance of about 90 Km (Zaid, 2012.). 
The aim of agricultural policy in El-Fayoum are to increase the land production throughout a better land use, improvement of the agricultural techniques and add new areas under cultivation to meet the future of stressing population demands.

Therefore, The intrinsic characteristics of agriculture make remote sensing (R.S.) an ideal technique for its monitoring and management (Zhongxin et. al., 2004). Remote Sensing (RS) in combination with GIS techniques proved to be more effective in soil sustainability and planning studies (DeVries, 1985). These advanced technologies (GIS and RS), which is "state-of-the-art" for handling geo-referenced data in a digital format. One major advantage of GIS is the integration of diverse database such as conventional maps and satellite imagery.

Land evaluation is concerned with the assessment of land performance when used for specified purposes (FAO, 1976). Although several land evaluation models have been developed to provide a quantified procedure to match land with various actual and proposed uses, there is no single or unified land evaluation modelling approach (Rossiter, 2003).

The land evaluation and mapping for EL-Fayoum depression area are essential actions in order to maintain the sustainable development of effort and investment as well as the sustainable usage of the soils (Bandyopadhyay et.al, 2009). Used to Storie Index (Storie, 1978) which revised by O'Geen and Southard (2005). Express numerically the relative degree of suitability of a soil for agricultural uses.

The objectives of this investigation are to setup a suitable geographic soil database that can used in the agricultural development, evaluate land resources, producing land capability maps for irrigated agriculture as well as land suitability maps for specific crops of El-Fayoum Depression.

\section{MATERIALS AND METHODS}

\section{1-General description of the studied area}

\section{a) Location:}

El-Fayoum Depression is located between latitudes $29^{\circ} 02^{`}$ and $29^{\circ} 35^{\circ} \mathrm{N}$ and longitudes $30^{\circ} 23^{\prime}$ and $31^{\circ} 05^{`}$ E. represents an area of about 441383 Feddans. It is one of the depressions in the limestone plateau of the Egyptian Western Desert. It is connected to the Nile valley by Bahr Yousif Channel. The topographic and hydrological boundaries are clear. Qarun Lake is located at the north-west in the bottom of the Depression (Figure1). 


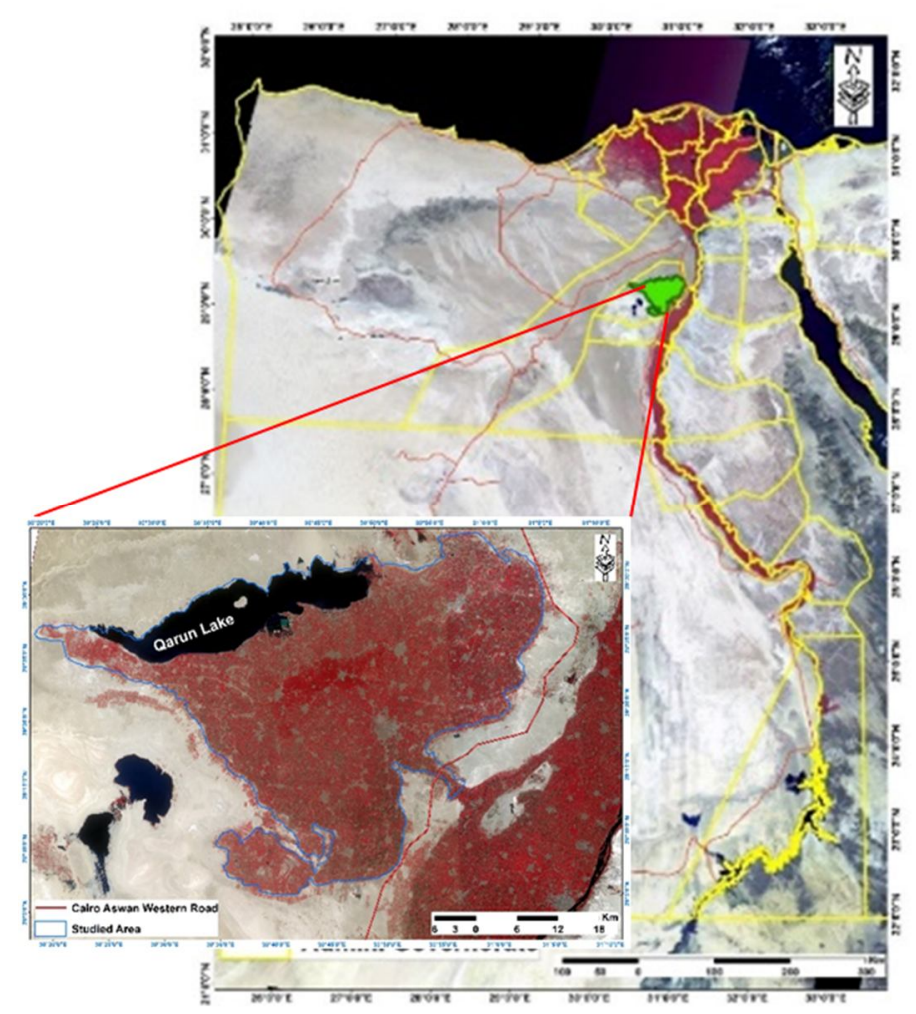

Figure 1. Location map of El-Fayoum Depression.

\section{b) Climate:}

El-Fayoum depression is characterized by a hot and dry summer with scanty winter rainfall and bright sunshine throughout the year. The annual temperature is $22.75{ }^{\circ} \mathrm{C}$; the average annual rainfall is $7 \mathrm{~mm}$, while the evaporation is $6.75 \mathrm{~mm} /$ day (Meteorological Authority, 2017).

According to the aridity index classes of Hulme and March (1990) El-Fayoum Depression is located under arid climatic condition.

\section{c) Geology:}

Said (2000) reported that the area of El-Fayoum depression was formed in the latter of Miocene and beginning of Pliocene periods. It occupies a portion of the Eocene limestone plateau at the northern part of the Western Desert and the subsurface lithology consists of marine sedimentary strata, which has undergone alternating periods of erosion and deposition. According to the geological map (scale 1: 500000), Nile Silt is the main formation which represents an area of about 363479 Feddans (82.3\% of El-Fayoum depression), followed by Mokattam Group (3.6 \% of El-Fayoum depression) as shown in Figure 2 and Table 1 (EGSA, 1988). 


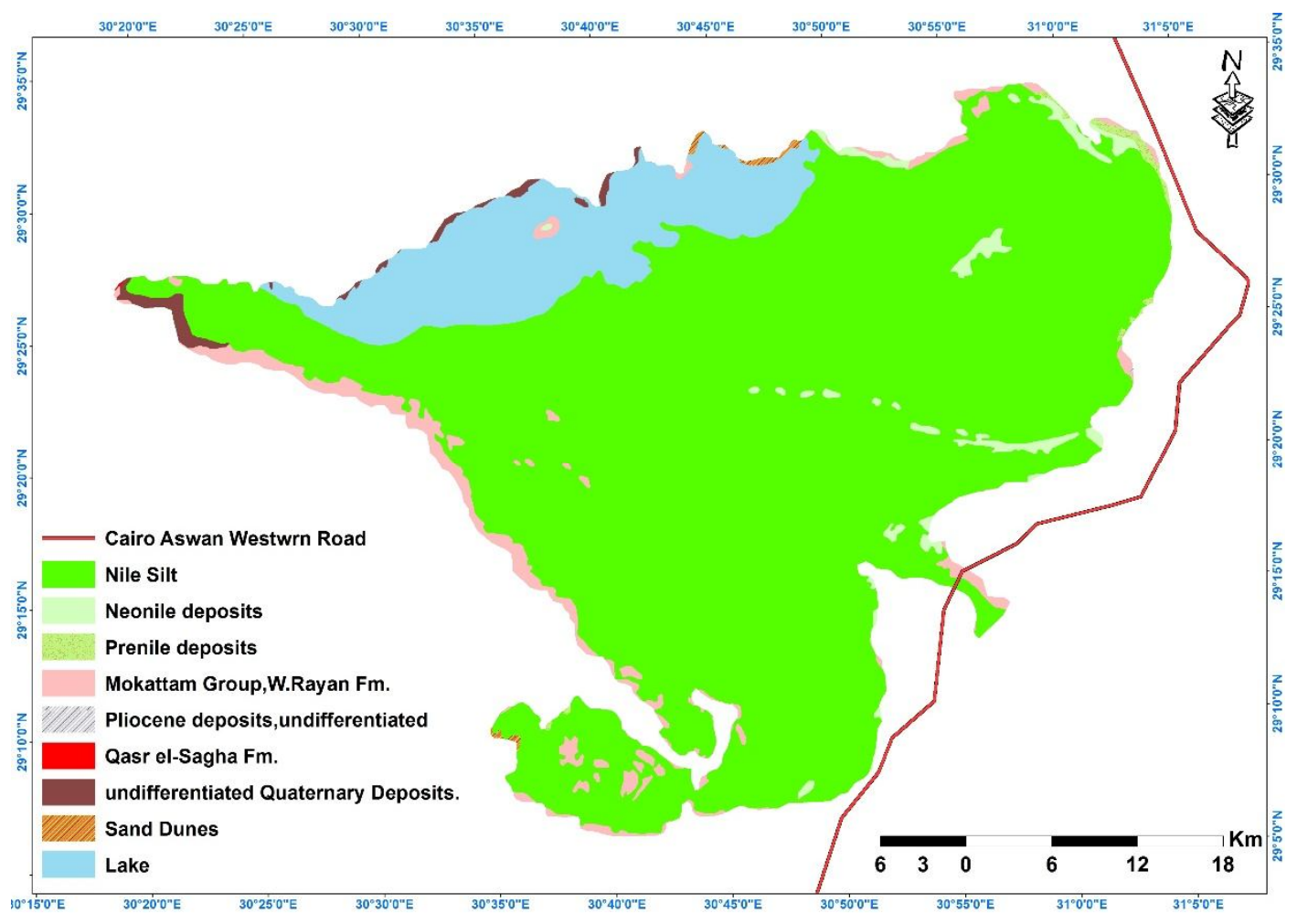

Figure 2. Geological map of El-Fayoum Depression

Table 1. Geological formations of El-Fayoum Depression (EGSA, 1988).

\begin{tabular}{|l|c|c|}
\hline \multicolumn{1}{|c|}{ Geology Formation } & Area (Feddans) & \% \\
\hline Nile Silt & 363479 & 82.4 \\
\hline Neonile deposits & 7004 & 1.5 \\
\hline Prenile deposits & 1398 & 0.3 \\
\hline Mokattam Group,W.Rayan Fm. & 15679 & 3.6 \\
\hline Pliocene deposits, undifferentiated & 11 & 0.0 \\
\hline Qasr el-Sagha Fm. & 26 & 0.0 \\
\hline Undifferentiated Quaternary Deposits. & 3047 & 0.7 \\
\hline Sand Dunes & 727 & 0.2 \\
\hline Lake & 50012 & 11.3 \\
\hline \multicolumn{1}{|c|}{ Total } & $\mathbf{4 4 1 3 8 3}$ & $\mathbf{1 0 0}$ \\
\hline
\end{tabular}

\section{d) Digital Elevation Model (DEM):}

The use of contour lines and spot heights of geo-statistical analysis through interpolation Kriging inverse distance method, which used the semi-variogram parameters (Stein, 1998). Was used to present the elevations of El-Fayoum Depression.

\section{e) Satellite data:}

Sentinel-2A high-resolution visible and infrared sensor (10 $\mathrm{m}$ spatial resolution) acquired in March 2017 used for delineating the physiographic units (Zinck, 1988) of the studied area using the visual analysis, by aid topographic maps, geology map and 
Digital Elevation Model (DEM). Spatial enhancement was done to have an output image with enhanced edges that related to soil. The pixel values are not manipulated individually but in relation to their four neighbors. This modifies the value of each pixel on neighboring brightness values (Daels, 1986). Colour enhancement was conducted to create new images from original to increase the amount of information that can be visually interpreted from the data.

The data and the output maps used the parameters for GIS displays were Egyptian Transverse Mercator (ETM) projection (Daels, 1986).

\section{Field Work:}

Twenty-five soil profiles were taken to represent the different mapping units of the studied area. Seventy-two minipits were used for checking the boundaries between mapping units. Morphological descriptions were worked out for the soil profiles in the field according to FAO (2006). Soil representative samples of the different layers of soil profiles were taken for laboratory analyses

\section{Laboratory Analyses:}

The collected disturbed soil samples were air dried, crushed and prepared for laboratory analyses, to determine some soil chemical and physical properties (USDA, 2004).

Laboratory analyses were conducted for particle size distribution using the pipette method, calcium carbonate content, gypsum content by precipitation with acetone, soil pH in the soil paste, salinity (ECe) in the soil paste extract, cation exchange capacity and exchangeable sodium percentage. Furthermore, the studied soils were classified according to the Soil Taxonomy System (USDA, 2014).

\section{4- Land Evaluation:}

Land evaluation for agricultural capability was assessed according to Storie Index (O'Geen and Southard, 2005) as a method for land evaluation according to the equation:

Storie index $=$ Factor $\mathrm{A} / 100 \times$ Factor $\mathrm{B} / 100 \times$ Factor $\mathrm{C} / 100 \times$ Factor $\mathrm{X} / 100 \times 100$

These factors are: (A) soil depth, (B) texture of the surface soil, (C) slope and (X) other limitations factors (drainage and salts). Each of these four general factors is evaluated on the basis of a "100 percent" rating. A rating of 100 percent expresses the most favorable, or ideal condition, and lower percentage ratings are given for conditions less favorable for crop production, as shown in table 2: 
Table 2. Capability grades classified (according to the value of Storie Index (O'Geen and Southard, 2005) as follows:

\begin{tabular}{|c|c|c|}
\hline \\
\hline Grade & Index Rating & Definition \\
\hline $\begin{array}{l}1- \\
\text { Excellent }\end{array}$ & $\begin{array}{l}80 \text { through } \\
100\end{array}$ & $\begin{array}{l}\text { Soils are well suited to intensive use for growing } \\
\text { irrigated crops. }\end{array}$ \\
\hline 2-Good & 60 through 79 & Soils are good agricultural soils. \\
\hline 3 - Fair & 40 through 59 & $\begin{array}{l}\text { Soils are only fairly well suited to general } \\
\text { agricultural use and are limited. }\end{array}$ \\
\hline 4 - Poor & 20 through 39 & $\begin{array}{l}\text { Soils are poorly suited. They are severely limited in } \\
\text { their agricultural potential. }\end{array}$ \\
\hline $\begin{array}{l}5 \text { - Very } \\
\text { Poor }\end{array}$ & 10 through 19 & $\begin{array}{l}\text { Soils are very poorly suited for agriculture and } \\
\text { seldom cultivated }\end{array}$ \\
\hline $\begin{array}{l}6 \text { - Non- } \\
\text { agricultural }\end{array}$ & Less than 10 & $\begin{array}{l}\text { Soils are not suited for agriculture at all due to very } \\
\text { severe to extreme physical limitations. }\end{array}$ \\
\hline
\end{tabular}

\section{Land evaluation assessment for certain crops:}

The assessment of land suitability for four different land use types (LUT) has been conducted for soil units (Sys et al, 1993) by implementing the FAO Framework for Land Evaluation (FAO, 1976). Soil characteristics of the different mapping units were compared and matched with the requirements of each crop.

\section{RESULTS AND DISCUSSION}

\section{Digital Elevation Model (DEM):}

Results shown in (Figure 3) the high areas located in the southeast side where as the elevation ranged from 15.2 to 35 meter above sea level. The low areas located adjacent to Qarun Lake whereas the elevation between 23.6 and 4.5 meter below sea level. 


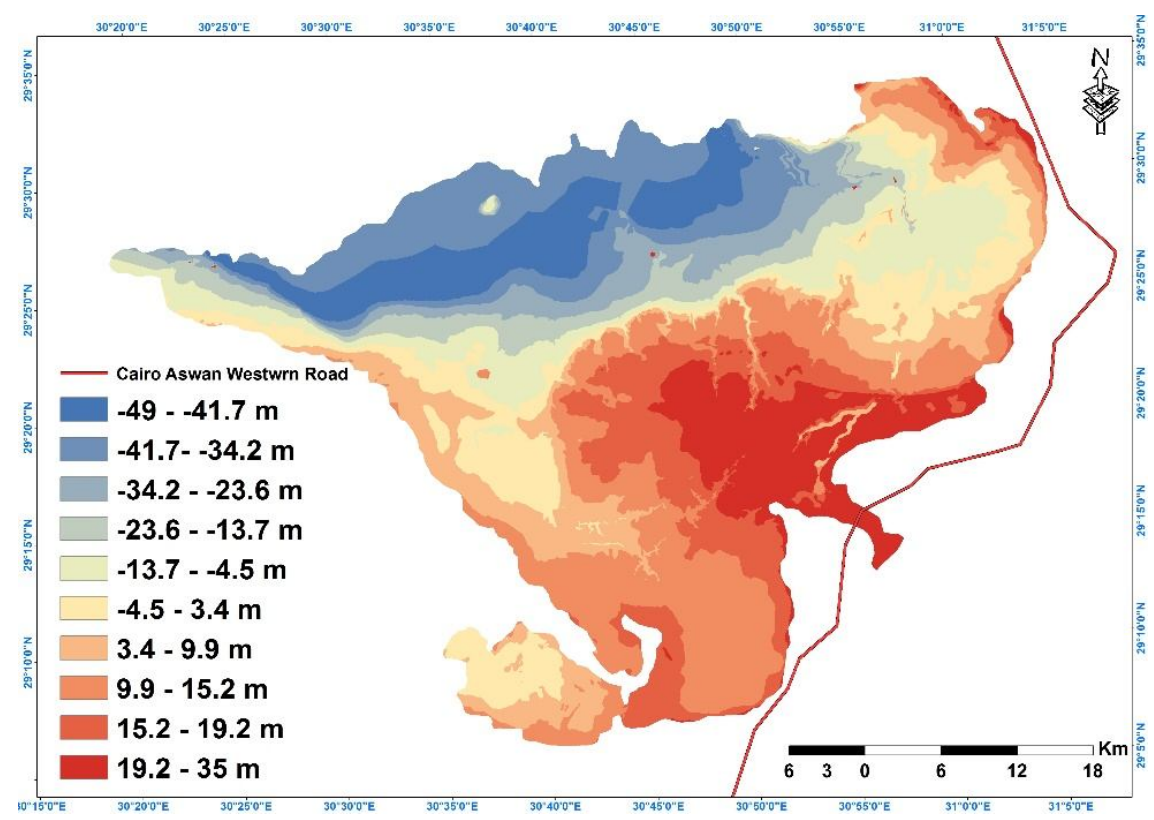

Figure 3. Digital Elevation Model (DEM) of the studied area

\section{Physiographic map:}

Visual interpretation of sentinel 2 image was done on false colour composite of bands 5, 3, 2 (scale 1:50000) to produce a base map according to the difference in landscape from the fieldwork activities. The integration between geology, Digital Elevation Model and visual interpretation was carried out to produce a base map. This base map was used in the field to check, confirm, correct and modify the mapping unit boundaries, coupled with the results of the field work to produce final physiographic soil map of the studied area (Figure 4 and Table 3).

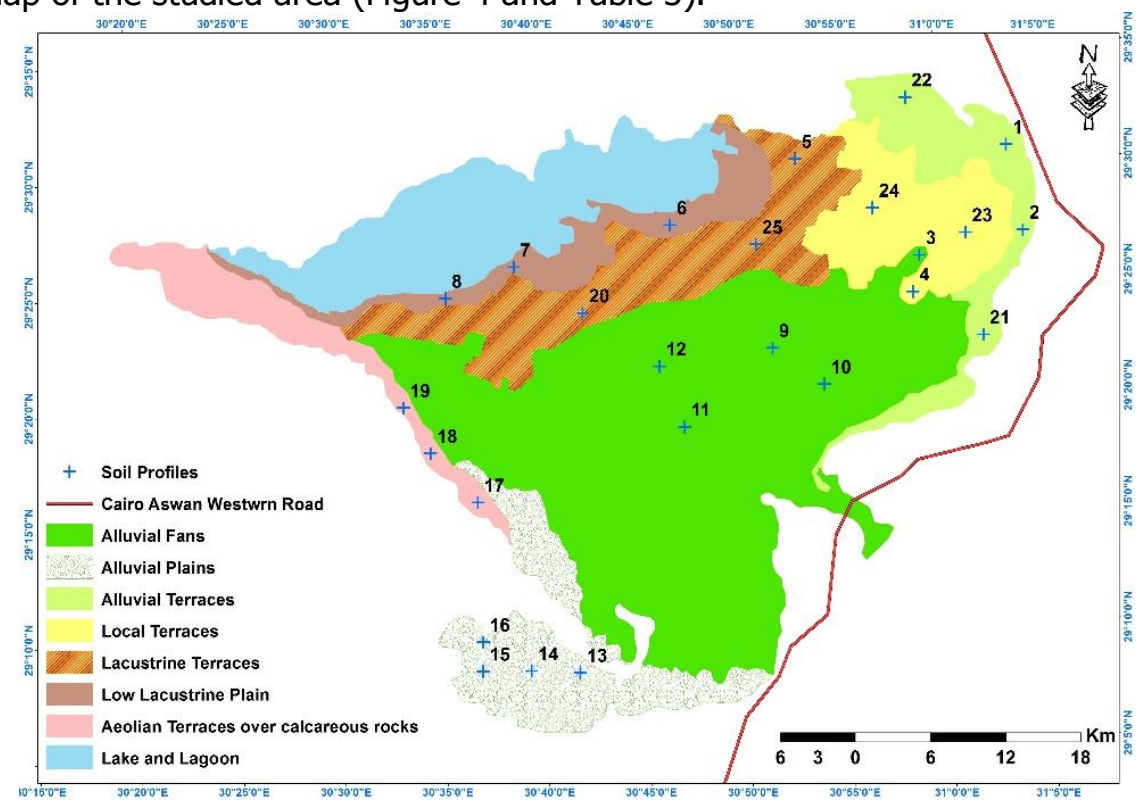

Figure 4. Location of soil profiles and physiographic map (Zinck, 1988) 
Table 3. Physiographic map legend

\begin{tabular}{|c|c|c|c|c|c|}
\hline \multirow{2}{*}{$\begin{array}{c}\text { Landscape } \\
\text { Unit } \\
\end{array}$} & \multirow{2}{*}{ Relief } & \multirow{2}{*}{$\begin{array}{c}\text { Lithology } \\
\text { (origin) }\end{array}$} & \multirow{2}{*}{ Mapping Unit } & \multicolumn{2}{|c|}{ Area } \\
\hline & & & & Fed. & $\%$ \\
\hline \multirow{4}{*}{$\begin{array}{l}\text { Alluvial Plains } \\
\text { (AP) }\end{array}$} & \multirow{4}{*}{$\begin{array}{l}\text { Flat to almost } \\
\text { flat }\end{array}$} & \multirow{4}{*}{$\begin{array}{l}\text { Alluvial } \\
\text { deposits }\end{array}$} & Alluvial fan & 187146 & 42.40 \\
\hline & & & Alluvial plain & 37765 & 8.56 \\
\hline & & & Alluvial Terraces & 29607 & 6.71 \\
\hline & & & Local Terraces & 33167 & 7.51 \\
\hline \multirow{2}{*}{$\begin{array}{l}\text { Lacustrine Plains } \\
\text { (LP) }\end{array}$} & \multirow{2}{*}{$\begin{array}{l}\text { Flat to almost } \\
\text { flat }\end{array}$} & \multirow{2}{*}{$\begin{array}{l}\text { Lacustrine } \\
\text { deposits }\end{array}$} & Lacustrine Terraces & 50986 & 11.55 \\
\hline & & & Low Lacustrine Plain & 23251 & 5.27 \\
\hline $\begin{array}{l}\text { Aeolian Plains } \\
(\mathrm{AL})\end{array}$ & $\begin{array}{l}\text { Gently } \\
\text { Undulating }\end{array}$ & Limestone & $\begin{array}{l}\text { Aeolian Terraces over } \\
\text { calcareous rocks }\end{array}$ & 21450 & 4.86 \\
\hline Lake and Lagoon & - & - & - & 58012 & 13.14 \\
\hline Total & & & & 441383 & 100.00 \\
\hline
\end{tabular}

Results show that, there are four landscape units representing El-Fayoum Depression, Alluvial Plains (AP) represent an area of about $65.18 \%$ of El-Fayoum depression with topography is flat to almost flat, Lacustrine Plain (LP) represent about $16.82 \%$ of El-Fayoum depression, Aeolian Plain (AL) represent about $4.86 \%$ of ElFayoum depression with surface is gently undulating and Lake and Lagoon located in the western north of El-Fayoum depression and represent about $13.14 \%$.

\section{Soil Properties of mapping units:}

\section{a. Mapping Unit of alluvial fan:}

This unit is represented by profiles Nos. 3,9,10, 11 and 12 and covered an area of about 187146 Feddans ( $42.40 \%$ of El-Fayoum depression). The soils of this unit are very deep (more than $120 \mathrm{~cm}$ in depth). Table 4, reveals that texture classes of the representative soil profiles of this unit varied from sand to clay, whereas clay content ranged from 1.75 to $45.0 \%$. CaCO3 content ranged between 0.8 and $14.0 \%$ with a tendency to decrease with soil profile depths. Gypsum content varied from 0.1 to $5.5 \%$. $\mathrm{pH}$ values from 7.4 to 7.7 indicating that these soils are slightly to moderately alkaline. The Soils are non-saline to extremely saline where ECe values ranged from 1.8 to 60.1 $\mathrm{dS} \mathrm{m}$ and their content in profile 3 are enough to the requirements of Salic horizon. CEC values ranged between 3.0 to $31.7 \mathrm{Cmole} / \mathrm{Kg}$, while ESP values varied from 1.8 to 40.6. The soils are classified into Typic Salitorrerts, Typic Torrifluvents, Typic Torripsamments and Vertic Torriorthents according to USDA (2014) as shown in Table 5.

\section{b. Mapping Unit of alluvial plain:}

This unit is covering an area of about 37765 Feddans (8.56 \% of El-Fayoum depression) and representing by soil profiles Nos. $13,14,15$ and 16 . The soils of this unit are moderately deep (less than $100 \mathrm{~cm}$ in depth) except for profile No. 13 where the soil of profile depth is shallow (less than $50 \mathrm{~cm}$ in depth). Data in Table 4 showed that soil texture classes ranged from loamy sand to loam throughout the entire profile depth. Calcium carbonate content ranged from 0.2 to $12.7 \%$ and their content are not 
enough to the requirements of calcic horizon. Gypsum content is very low not exceeds $0.4 \%$. $\mathrm{pH}$ values from 7.3 to 7.9 . Soils are non-saline to moderately saline, where. ECe of soil past extract ranged from 1.6 to $12.3 \mathrm{dS} / \mathrm{m}$. CEC values varied from narrow limit from 3.7 to $14.6 \mathrm{Cmole} / \mathrm{Kg}$. Exchangeable sodium percentage was generally less than $15 \%$, i.e. these soils are non-sodic. The soils are classified into Lithic Torriorthents, Typic Torriorthents, Typic Torrifluvents and Typic Torripsamments according to USDA (2014) as shown in Table 5.

\section{c. Soil Mapping Unit of alluvial terraces:}

This unit represented by profiles 1, 2, 21 and 22 and covered an area of about 29607 Feddans ( $6.71 \%$ of El-Fayoum depression). The soils of this unit are moderately deep (less than $100 \mathrm{~cm}$ in depth). Table 4 reveals that the dominant texture is varied from sand to sandy clay loam. Calcium carbonate is as high and varied from 6.2 to $17.5 \%$ and their contents in profile No. 1 are enough to requirements of calcic horizon. Gypsum content varied from 0.6 to $3.2 \%$ with tendency to decrease with soil profile depths. The soils of this physiographic units were slightly to strongly alkaline where $\mathrm{pH}$ values varied from 7.5 to 8.6. Soil salinity values indicated that these soils were slightly to extremely saline as ECe values varied from 2.1 to $49.7 \mathrm{dS} / \mathrm{m}$. CEC values ranged from 3.0 to $18.3 \mathrm{Cmole} / \mathrm{Kg}$, and ESP varied from 8.6 to $37.7 \%$ indicating that the soils of profiles 1.2 and 22 were sodic soils. These soils are classified into Calcic Haplosalids, Typic Haplosalids and, Typic Torriorthents according to USDA (2014) as shown in Table 5.

\section{d. Mapping Unit of local terraces:}

This unit is covering an area of about 33167 Feddans (7.51 \% of El-Fayoum depression) and representing by soil profiles Nos. 4, 23 and 24 . The soils of this unit are moderately deep (less than $100 \mathrm{~cm}$ in depth), soil texture ranged from loam to clay. Calcium carbonate content ranged between 8.5 to $13.8 \%$. with an increase with soil profiles depth. Gypsum content is very low not exceeds $3.9 \%$. The soils are slightly to moderately alkaline where the values of $\mathrm{pH}$ ranged from 7.6 to 8.1 . Salinity values of these soils were non-to strongly saline as shown by ECe values ranged from 1.1 to 28.8 $\mathrm{dSm}^{-1}$. CEC values ranged from 15.6 to $30.8 \mathrm{Cmole} / \mathrm{Kg}$. The CEC variation reflects differences in clay and silty content among the soil profiles and their layers. ESP values varied from 4.9 to $29.1 \%$. The soils are classified into Typic Torriorthents and Sodic Haplotorrerts according to USDA (2014) as shown in Table 5.

\section{e. Mapping Unit of lacustrine terraces:}

Data in Table 3 showed that this unit was covering an area of about 50986 Feddans (11.55\% of El-Fayoum depression) and representing by soil profiles Nos. 5, 20, and 25. The soils of this unit were moderately deep (less than $100 \mathrm{~cm}$ in depth), the dominant texture is varied from sand to clay. $\mathrm{CaCO} 3$ content was very low and varied from 2.6 to $8.5 \%$, while gypsum content ranged from 0.1 to $3.2 \%$. Their content of 
$\mathrm{CaCO} 3$ and gypsum were not enough to the requirements of calcic and gypsic horizons. Data in table 4 indicate that the $\mathrm{pH}$ values varied from 7.6 to 8.4 showing that soils were slightly to moderatly alkaline. Slightly to extremely saline, where ECe of soil past extract ranged from 3.4 to $36.1 \mathrm{dS} / \mathrm{m}$. The cation exchange capacity (CEC) ranged from 4.1 to $35.6 \mathrm{Cmole} / \mathrm{kg}$ and ESP varied from 4.2 to $26.4 \%$ indicating that the soils of profiles 20 and 25 were sodic soils. The soils are classified into Typic Haplosalids, Typic Torripsamments and Typic Torriorthents according to USDA (2014) as shown in Table 5.

\section{f. Mapping Unit of low lacustrine plain:}

This unit is adjacent closely to the Qaroun Lake. It covers an area of about 23251 Feddans (5.27 \% of El-Fayoum depression) and represented by profiles No. 6, 7, and 8 . The soils of this unit were moderately deep (less than $100 \mathrm{~cm}$ in depth), the dominant texture is varied from loamy sand to clay loam. Table 4 indicated that $\mathrm{CaCO} 3$ and gypsum content varied from 8.7 to $14.0 \%$ and 0.2 to $3.6 \%$, respectively. The soil reaction $(\mathrm{pH})$ ranged between 7.7 and 8.4 indicating that these soils were slightly to moderatly alkaline. Soil salinity varied in wide range among the studied soil profiles and ranged between 5.1 and $53.8 \mathrm{dS} / \mathrm{m}$ which means that the soils were slightly to extremely saline. Cation exchange capacity (CEC) values ranged from 6.2 and 27.0 Cmole/kg. These high CEC values may be attributed to the high content of clay fraction. ESP had strong variation, as it ranged from 1.4 to $71.4 \%$ depending upon the concentration of $\mathrm{Na}^{+}$and $\mathrm{Ca}^{++}$and $\mathrm{Mg}^{++}$ions. The soils are classified into Typic Haplosalids and Typic Torrifluvents as inclusion according to USDA (2014) as shown in Table 5.

\section{g. Mapping Unit of Aeolian terraces over calcareous rocks:}

This unit covers an area of about 21450 Feddans ( $4.86 \%$ of the total studied area) and represented by profiles No. 17,18 , and 19 . The soils of this unit are shallow deep (less than $50 \mathrm{~cm}$ in depth), the dominant texture is generally coarse with very low percentage of clay and silt. Sand percentage ranged between $83.1 \%$ and $95.84 \%$ which means that the dominate class of soil texture is sand (table 4). $\mathrm{CaCO}_{3}$ content ranged widely from $5.4 \%$ to $14.8 \%$, while gypsum content was considerably low ranging from 0.4 to $4.6 \%$. Soil reaction was slightly to moderatly alkaline, the soils were moderatly to strongly saline as shown by ECe values which ranged from 12.5 to $21.4 \mathrm{dS} / \mathrm{m}$. CEC values varied from 3.5 to $5.9 \mathrm{Cmole} / \mathrm{kg}$, while exchangeable sodium percent (ESP) in the investigated soils ranged from 5.4 to $17.2 \%$. The soils are classified into Lithic Torripsamments according to USDA (2014) as shown in Table 5. 
Table 4. Some chemical and physical properties of the studied mapping units

\begin{tabular}{|c|c|c|c|c|c|c|c|c|c|c|c|c|c|}
\hline Mapping Unit & $\begin{array}{c}\begin{array}{c}\text { Profile } \\
\text { No }\end{array} \\
\end{array}$ & $\begin{array}{l}\text { Depth } \\
\text { (cm) }\end{array}$ & pH & $\begin{array}{c}E C \\
(d S / m)\end{array}$ & $\begin{array}{c}\text { Coarse } \\
\text { Sand } \\
(\%)\end{array}$ & $\begin{array}{l}\text { Fine } \\
\text { Sand } \\
(\%)\end{array}$ & $\begin{array}{l}\text { Silt } \\
(\%)\end{array}$ & $\begin{array}{l}\text { Clay } \\
(\%)\end{array}$ & $\begin{array}{l}\text { Texture } \\
\text { Class** }\end{array}$ & $\begin{array}{c}\mathrm{CaCO}_{3} \\
(\%)\end{array}$ & $\begin{array}{c}\text { Gypsum } \\
(\%)\end{array}$ & $\begin{array}{l}\text { ESP } \\
(\%)\end{array}$ & $\begin{array}{c}\text { CEC } \\
\text { (Cmole/kg) }\end{array}$ \\
\hline \multirow{16}{*}{ Alluvial fan } & \multirow{4}{*}{3} & $0-30$ & 7.70 & 20.20 & 22.74 & 10.61 & 25.15 & 41.50 & $C$ & 12.70 & 0.10 & 20.00 & 31.50 \\
\hline & & $30-60$ & 7.70 & 29.10 & 18.40 & 9.20 & 31.15 & 41.25 & C & 11.30 & 5.50 & 18.00 & 31.70 \\
\hline & & $60-90$ & 7.40 & 60.10 & 21.87 & 9.51 & 32.12 & 36.50 & $\mathrm{CL}$ & 14.00 & 0.10 & 40.60 & 21.40 \\
\hline & & $90-120$ & 7.50 & 56.20 & 23.17 & 5.56 & 32.38 & 38.89 & $\mathrm{CL}$ & 13.50 & 1.10 & 37.90 & 22.70 \\
\hline & \multirow{3}{*}{9} & $0-30$ & 7.60 & 4.10 & 47.95 & 12.99 & 31.81 & 7.25 & $\mathrm{SL}$ & 4.30 & 0.30 & 4.50 & 8.60 \\
\hline & & $30-60$ & 7.70 & 2.40 & 40.85 & 20.63 & 12.77 & 25.75 & $\mathrm{SCL}$ & 3.90 & 0.10 & 2.00 & 23.20 \\
\hline & & $60-120$ & 7.60 & 1.80 & 43.69 & 23.04 & 21.27 & 12.00 & $\mathrm{SL}$ & 3.50 & 0.20 & 2.70 & 10.30 \\
\hline & \multirow{3}{*}{10} & $0-25$ & 7.50 & 2.90 & 58.64 & 22.65 & 7.21 & 11.50 & $\mathrm{SL}$ & 5.20 & 0.30 & 1.80 & 11.10 \\
\hline & & $25-60$ & 7.60 & 2.40 & 74.30 & 13.96 & 8.34 & 3.40 & $\mathrm{~S}$ & 1.30 & 0.30 & 2.00 & 3.60 \\
\hline & & $60-120$ & 7.70 & 2.30 & 73.98 & 17.13 & 7.14 & 1.75 & $\mathrm{~s}$ & 0.80 & 0.30 & 3.00 & 3.00 \\
\hline & \multirow{3}{*}{11} & $0-30$ & 7.50 & 2.90 & 23.25 & 13.63 & 32.87 & 30.25 & $\mathrm{CL}$ & 6.50 & 0.10 & 6.50 & 16.10 \\
\hline & & $30-60$ & 7.40 & 9.10 & 10.75 & 17.25 & $35 . .50$ & 36.50 & $\mathrm{CL}$ & 5.20 & 0.10 & 5.70 & 22.70 \\
\hline & & $60-130$ & 7.50 & 12.00 & 4.30 & 21.58 & 35.37 & 38.75 & $\mathrm{CL}$ & 4.80 & 0.10 & 5.30 & 23.70 \\
\hline & \multirow{3}{*}{12} & $0-30$ & 7.50 & 2.60 & 15.81 & 16.15 & 42.34 & 25.70 & $L$ & 4.30 & 0.10 & 4.90 & 14.30 \\
\hline & & $30-60$ & 7.50 & 3.40 & 4.85 & 13.32 & 36.83 & 45.00 & $C$ & 3.50 & 0.10 & 6.10 & 30.60 \\
\hline & & $60-130$ & 7.40 & 4.20 & 4.28 & 11.83 & 41.14 & 42.75 & $\mathrm{SiC}$ & 2.60 & 0.10 & 8.30 & 30.50 \\
\hline \multirow{10}{*}{ Alluvial plain } & 13 & $0-40$ & 7.40 & 2.40 & 29.50 & 33.75 & 18.75 & 18.00 & SL & 3.60 & 0.20 & 1.70 & 10.80 \\
\hline & \multirow{3}{*}{14} & $0-25$ & 7.60 & 4.20 & 55.59 & 10.54 & 17.12 & 16.75 & $\mathrm{SL}$ & 6.50 & 0.10 & 5.30 & 11.30 \\
\hline & & $25-50$ & 7.70 & 4.80 & 57.97 & 4.76 & 17.52 & 19.75 & $\mathrm{SL}$ & 6.10 & 0.10 & 5.00 & 11.20 \\
\hline & & $50-90$ & 7.90 & 6.50 & 34.78 & 15.01 & 37.81 & 12.40 & $\mathrm{~L}$ & 12.70 & 0.10 & 5.70 & 14.60 \\
\hline & \multirow{3}{*}{15} & $0-30$ & 7.80 & 12.30 & 67.37 & 11.35 & 16.78 & 4.50 & LS & 8.70 & 0.10 & 8.70 & 5.60 \\
\hline & & $30-60$ & 7.60 & 3.50 & 72.96 & 7.32 & 6.72 & 13.00 & $\mathrm{SL}$ & 7.80 & 0.20 & 3.80 & 8.10 \\
\hline & & $60-90$ & 7.40 & 3.40 & 77.95 & 9.80 & 6.50 & 5.75 & LS & 6.10 & 0.20 & 3.80 & 3.70 \\
\hline & \multirow{3}{*}{16} & $0-25$ & 7.30 & 1.70 & 74.47 & $\begin{array}{l}4.44 \\
\end{array}$ & 15.59 & 5.50 & LS & 0.90 & 0.40 & 0.90 & 7.10 \\
\hline & & $25-50$ & 7.60 & 1.60 & 82.80 & 4.76 & 2.19 & 10.25 & LS & 1.50 & 0.30 & 1.60 & 7.70 \\
\hline & & $50-100$ & 7.50 & 3.50 & 79.20 & 5.67 & 2.83 & 12.30 & LS & 0.20 & 0.20 & 3.90 & 6.60 \\
\hline \multirow{6}{*}{ Alluvial terraces } & \multirow{3}{*}{1} & $0-30$ & 8.60 & 49.70 & 68.16 & 14.25 & 9.84 & 7.75 & LS & 12.20 & 1.60 & 37.70 & 5.30 \\
\hline & & $30-40$ & 8.40 & 17.60 & 89.99 & 4.39 & 1.50 & 4.12 & $\mathrm{~S}$ & 17.50 & 0.60 & 25.00 & 3.80 \\
\hline & & $40-90$ & 8.30 & 25.30 & 81.17 & 9.19 & 5.70 & 3.94 & $\mathrm{~S}$ & 10.50 & 0.80 & 30.30 & 3.10 \\
\hline & \multirow{3}{*}{2} & $0-35$ & 7.50 & 43.20 & 73.45 & 11.22 & 7.08 & 8.25 & LS & 14.00 & 1.30 & 29.60 & 7.70 \\
\hline & & $35-50$ & 7.70 & 29.40 & 75.54 & 10.20 & 6.96 & 7.30 & LS & 12.20 & 1.00 & 25.40 & 5.60 \\
\hline & & $50-90$ & 7.90 & 13.40 & 86.88 & 6.64 & 1.75 & 4.73 & $\mathrm{~S}$ & 12.70 & 0.80 & 19.60 & 3.00 \\
\hline
\end{tabular}
${ }^{* *} \mathrm{~S}=$ Sand
LS = Loamy Sand
$\mathrm{SL}=$ Sandy Loam
$\mathrm{L}=\mathrm{Loam}$
$\mathrm{SCL}=$ Sandy
Clay Loam $\mathrm{CL}=$ Clay Loam
$\mathrm{SiC}=$ Silty Clay
$\mathrm{C}=$ Clay 
Table 4. Cont.

\begin{tabular}{|c|c|c|c|c|c|c|c|c|c|c|c|c|c|}
\hline Mapping Unit & $\begin{array}{c}\text { Profile } \\
\text { No }\end{array}$ & $\begin{array}{l}\text { Depth } \\
\text { (cm) }\end{array}$ & pH & $\begin{array}{c}\text { EC } \\
(\mathrm{dS} / \mathrm{m})\end{array}$ & $\begin{array}{l}\text { Coarse } \\
\text { Sand } \\
(\%)\end{array}$ & $\begin{array}{l}\text { Fine } \\
\text { Sand } \\
(\%)\end{array}$ & $\begin{array}{l}\text { Silt } \\
(\%)\end{array}$ & $\begin{array}{l}\text { Clay } \\
(\%)\end{array}$ & $\begin{array}{l}\text { Texture } \\
\text { Class }^{* *}\end{array}$ & $\begin{array}{c}\mathrm{CaCO}_{3} \\
(\%)\end{array}$ & $\begin{array}{c}\text { Gypsum } \\
(\%)\end{array}$ & $\begin{array}{l}\text { ESP } \\
(\%)\end{array}$ & $\begin{array}{c}\text { CEC } \\
(\mathrm{Cmole} / \mathrm{kg})\end{array}$ \\
\hline \multirow{4}{*}{ Alluvial terraces } & \multirow{2}{*}{21} & $0-25$ & 7.70 & 4.30 & 2.80 & 29.50 & 40.30 & 27.70 & $\mathrm{~L}$ & 6.20 & 3.20 & 9.80 & 14.60 \\
\hline & & $25-85$ & 7.60 & 4.20 & 41.82 & 19.35 & 16.58 & 22.25 & $\mathrm{SCL}$ & 8.10 & 2.90 & 8.60 & 17.80 \\
\hline & \multirow[b]{2}{*}{22} & $0-25$ & 7.60 & 2.10 & 23.10 & 37.50 & 14.70 & 24.50 & $\mathrm{SCL}$ & 10.50 & 1.10 & 18.60 & 17.40 \\
\hline & & $25-75$ & 7.50 & 2.40 & 15.90 & 43.20 & 12.70 & 28.20 & $\mathrm{SCL}$ & 9.50 & 0.60 & 23.70 & 18.30 \\
\hline \multirow{8}{*}{ Local terraces } & \multirow{3}{*}{4} & $0-10$ & 7.60 & 28.80 & 22.93 & 10.43 & 39.89 & 22.75 & $\mathrm{~L}$ & 10.90 & 3.90 & 25.20 & 15.60 \\
\hline & & $10-40$ & 7.90 & 17.00 & 8.14 & 13.84 & 32.52 & 45.50 & $\mathrm{C}$ & 12.70 & 0.40 & 29.10 & 30.80 \\
\hline & & $40-100$ & 8.10 & 11.50 & 5.72 & 19.79 & 29.84 & 44.65 & $C$ & 13.10 & 0.10 & 12.20 & 30.40 \\
\hline & \multirow[b]{2}{*}{23} & $0-35$ & 7.90 & 2.40 & 14.04 & $\begin{array}{ll}36.78 \\
\end{array}$ & 19.33 & 29.85 & $\mathrm{SCL}$ & 9.50 & 1.60 & 11.60 & 28.30 \\
\hline & & $35-100$ & 8.00 & 1.10 & 15.82 & 36.10 & 12.93 & 35.15 & $\mathrm{SCL}$ & 8.50 & 1.70 & 13.80 & 19.10 \\
\hline & \multirow{3}{*}{24} & $0-25$ & 7.80 & 1.80 & 29.67 & 19.03 & 17.51 & 33.79 & $\mathrm{SCL}$ & 11.50 & 2.80 & 8.30 & 24.50 \\
\hline & & $25-75$ & 7.90 & 3.90 & 22.05 & 25.55 & 25.23 & 27.17 & $\mathrm{SCL}$ & 10.50 & 2.80 & 5.10 & 26.80 \\
\hline & & $75-100$ & 7.70 & 3.80 & 1.82 & 44.95 & 30.78 & 22.45 & $\mathrm{~L}$ & 13.80 & 3.90 & 4.90 & 18.40 \\
\hline \multirow{8}{*}{$\begin{array}{l}\text { Lacustrine } \\
\text { terraces }\end{array}$} & \multirow{3}{*}{$\mathbf{5}$} & $0-30$ & 7.90 & 7.40 & 73.83 & 8.64 & 11.05 & 6.48 & LS & 4.30 & 0.20 & 6.70 & 5.80 \\
\hline & & $30-60$ & 8.00 & 3.40 & 69.28 & 12.17 & 8.30 & 10.25 & LS & 4.80 & 0.30 & 5.00 & 4.10 \\
\hline & & $60-100$ & 8.00 & 3.90 & 91.20 & $\begin{array}{l}4.81 \\
\end{array}$ & 2.29 & 1.70 & $\mathrm{~S}$ & 2.60 & 0.10 & 4.20 & 4.80 \\
\hline & \multirow{3}{*}{20} & $0-30$ & 7.60 & 36.10 & 8.96 & 22.73 & 30.81 & 37.50 & $\mathrm{CL}$ & 5.50 & 1.20 & 26.40 & 21.00 \\
\hline & & $30-60$ & 8.10 & 25.00 & 19.09 & 19.00 & 34.72 & 27.19 & $\mathrm{CL}$ & 5.50 & 0.1 & 19.40 & 17.40 \\
\hline & & $60-100$ & 8.20 & 20.20 & 20.78 & 19.70 & 27.02 & 32.50 & $\mathrm{CL}$ & 6.50 & 0.3 & 13.70 & 18.10 \\
\hline & \multirow{2}{*}{25} & $0-30$ & 8.00 & 5.30 & 2.60 & 36.90 & 12.50 & 48.10 & $\mathrm{C}$ & 8.50 & 2.60 & 17.20 & 35.60 \\
\hline & & $30-75$ & 8.40 & 6.60 & 2.80 & 39.40 & 25.20 & 32.60 & $\mathrm{CL}$ & 6.50 & 3.20 & 22.40 & 28.50 \\
\hline \multirow{9}{*}{$\begin{array}{l}\text { Low Lacustrine } \\
\text { Plain }\end{array}$} & \multirow{3}{*}{6} & $0-30$ & 8.20 & 48.80 & 19.15 & 20.63 & 30.50 & 29.72 & $\mathrm{CL}$ & 9.60 & 3.10 & 71.40 & 18.60 \\
\hline & & $30-60$ & 8.10 & 53.80 & 21.92 & 26.65 & 30.75 & 20.68 & $\mathrm{~L}$ & 8.70 & 3.60 & 52.90 & 18.20 \\
\hline & & $60-100$ & 8.40 & 43.10 & 9.22 & 30.33 & 33.25 & 27.20 & $\mathrm{CL}$ & 10.50 & 2.20 & 38.70 & 26.10 \\
\hline & \multirow{3}{*}{7} & $0-30$ & 8.20 & 7.00 & 40.73 & 19.70 & 21.82 & 17.75 & $S L$ & 12.70 & 0.20 & 9.20 & 10.60 \\
\hline & & $30-50$ & 8.20 & 6.10 & 41.82 & 18.35 & 17.58 & 22.25 & $\mathrm{SCL}$ & 12.70 & 0.30 & 6.90 & 27.00 \\
\hline & & $50-90$ & 8.20 & 6.40 & 78.78 & 7.12 & 4.60 & 9.50 & LS & 14.00 & 0.40 & 6.40 & 6.20 \\
\hline & \multirow{3}{*}{8} & $0-25$ & 8.00 & 5.10 & 24.38 & 27.52 & 32.35 & 15.75 & $L$ & 10.50 & 0.40 & 1.40 & 14.10 \\
\hline & & $25-50$ & 7.70 & 8.90 & 17.64 & 24.12 & 37.14 & 21.10 & $\mathrm{~L}$ & 10.90 & 2.60 & 2.80 & 13.40 \\
\hline & & $50-90$ & 7.90 & 11.30 & 14.65 & $\begin{array}{l}17.79 \\
\end{array}$ & 30.16 & 37.40 & $\mathrm{CL}$ & 12.20 & 2.60 & 6.70 & 21.70 \\
\hline \multirow{5}{*}{$\begin{array}{l}\text { Aeolian terraces } \\
\text { over calcareous } \\
\text { rocks }\end{array}$} & \multirow[b]{2}{*}{17} & $0-30$ & 7.8 & 21.4 & 73.4 & 12.47 & 8.09 & 6.0 & LS & 12.2 & 4.6 & 17.2 & 4.0 \\
\hline & & $30-40$ & 8.0 & 20.3 & 74.4 & 10.67 & 11.34 & 3.50 & LS & 14.8 & 4.5 & 13.5 & 4.5 \\
\hline & 18 & $0-40$ & 8.3 & 16.0 & 89.4 & $\begin{array}{l}6.44 \\
\end{array}$ & 2.82 & $\begin{array}{l}1.25 \\
\end{array}$ & $\mathrm{~S}$ & 14.5 & 0.4 & 10.5 & 3.6 \\
\hline & \multirow{2}{*}{19} & $0-10$ & 8.1 & 10.6 & 78.5 & 9.94 & 8.0 & 3.52 & $\mathrm{~S}$ & 8.0 & 3.1 & 5.4 & 3.5 \\
\hline & & $10-40$ & 7.9 & 12.5 & 69.6 & 13.50 & 15.69 & 1.20 & LS & 5.4 & 3.1 & 8.1 & 5.9 \\
\hline
\end{tabular}
${ }^{* *} \mathrm{~S}=$ Sand
LS = Loamy Sand
$\mathrm{SL}=$ Sandy Loam
$\mathrm{L}=\mathrm{Loam}$
$\mathrm{SCL}=$ Sandy
Clay Loam $\mathrm{CL}=$ Clay Loam
$\mathrm{SiC}=$ Silty Clay
$\mathrm{C}=$ Clay 
Table 5. Soil taxonomic units of the studied soil profiles.

\begin{tabular}{|c|c|c|c|c|c|}
\hline Order & $\begin{array}{l}\text { Sub } \\
\text { Order }\end{array}$ & $\begin{array}{l}\text { Great } \\
\text { group }\end{array}$ & $\begin{array}{c}\text { Sub } \\
\text { group }\end{array}$ & Family & $\begin{array}{l}\text { Prof. } \\
\text { No. }\end{array}$ \\
\hline \multirow{2}{*}{ 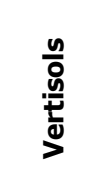 } & \multirow{2}{*}{ 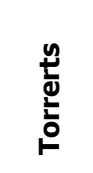 } & $\begin{array}{c}\text { Sali- } \\
\text { torrerts }\end{array}$ & $\begin{array}{c}\text { Typic } \\
\text { salitorrerts }\end{array}$ & \multirow[b]{2}{*}{ clayey, smectitic, hyperthermic, deep. } & 3 \\
\hline & & $\begin{array}{l}\text { Haplo- } \\
\text { torrerts }\end{array}$ & $\begin{array}{c}\text { Sodic } \\
\text { Haplotorrerts }\end{array}$ & & 4 \\
\hline \multirow{4}{*}{$\begin{array}{l}\frac{n}{0} \\
\frac{.9}{0} \\
\frac{0}{2}\end{array}$} & \multirow{4}{*}{ 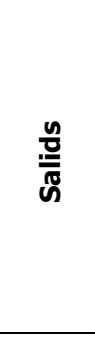 } & \multirow{4}{*}{ 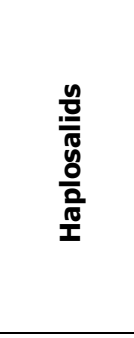 } & $\begin{array}{c}\text { Calcic } \\
\text { Haplosalids }\end{array}$ & $\begin{array}{l}\text { siliceous, hyperthermic, moderately } \\
\text { deep. }\end{array}$ & 1 \\
\hline & & & \multirow{3}{*}{$\begin{array}{l}\text { Typic } \\
\text { Haplosalids }\end{array}$} & $\begin{array}{l}\text { sandy, mixed, hyperthermic, } \\
\text { moderately deep. }\end{array}$ & 2 \\
\hline & & & & $\begin{array}{l}\text { fine loamy, mixed, hyperthermic, } \\
\text { deep. }\end{array}$ & 6 \\
\hline & & & & $\begin{array}{l}\text { fine loamy, mixed, hyperthermic, } \\
\text { deep. }\end{array}$ & 20 \\
\hline \multirow{14}{*}{$\begin{array}{l}\frac{n}{0} \\
\frac{n}{5} \\
\text { w }\end{array}$} & \multirow{5}{*}{ 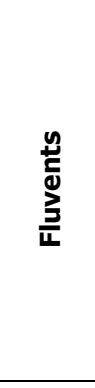 } & \multirow{5}{*}{ 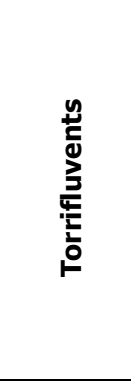 } & \multirow{5}{*}{$\begin{array}{l}\text { Typic } \\
\text { Torrifluvents }\end{array}$} & $\begin{array}{l}\text { fine loamy, over sandy skeletal, } \\
\text { mixed, hyperthemic, deep. }\end{array}$ & 7 \\
\hline & & & & $\begin{array}{l}\text { fine loamy, mixed, hyperthermic, } \\
\text { moderately deep. }\end{array}$ & 8 \\
\hline & & & & $\begin{array}{l}\text { fine loamy, over loamy, mixed, } \\
\text { hyperthermic, deep. }\end{array}$ & 9 \\
\hline & & & & clayey, mixed, hyperthermic, deep. & 12 \\
\hline & & & & $\begin{array}{l}\text { coarse, loamy over sandy, mixed, } \\
\text { hyperthermic, moderately deep. }\end{array}$ & 15 \\
\hline & \multirow{3}{*}{$\begin{array}{l}\stackrel{y}{E} \\
\stackrel{0}{ \pm} \\
\stackrel{ \pm}{0}\end{array}$} & \multirow{3}{*}{ 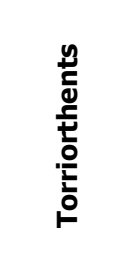 } & Lithic Torriorthents & loamy, mixed, hyperthermic, shallow. & 13 \\
\hline & & & $\begin{array}{l}\text { Vertic } \\
\text { Torriorthents }\end{array}$ & clayey, mixed, hyperthermic, deep. & 11 \\
\hline & & & Typic Torriorthents & $\begin{array}{l}\text { coarse loamy, mixed, hyperthermic, } \\
\text { moderately deep. }\end{array}$ & $\begin{array}{c}14, \\
21,22,23 \\
24,25\end{array}$ \\
\hline & \multirow{6}{*}{ 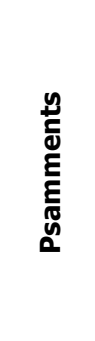 } & \multirow{6}{*}{ 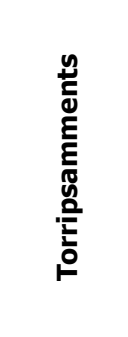 } & \multirow{3}{*}{$\begin{array}{l}\text { Typic } \\
\text { Torrripsamments }\end{array}$} & mixed, hyperthermic, deep. & 5 \\
\hline & & & & $\begin{array}{l}\text { siliceous, hyperthermic, moderatly } \\
\text { deep. }\end{array}$ & 10 \\
\hline & & & & $\begin{array}{l}\text { sandy, mixed, hyperthermic, } \\
\text { moderately deep. }\end{array}$ & 16 \\
\hline & & & \multirow{3}{*}{$\begin{array}{l}\text { Lithic } \\
\text { Torripsamments }\end{array}$} & mixed, hyperthermic, shallow. & 17 \\
\hline & & & & siliceous, hyperthermic, shallow. & 18 \\
\hline & & & & mixed, hyperthermic. Shallow. & 19 \\
\hline
\end{tabular}

\section{Land capability assessment}

A land capability model was built using Arc GIS 10.4 software (database) and the resulting tables were imported into Arc GIS to produce the capability map. The results of land capability indicate that capability degrees ranged from degree 1 to degree 5 (Figure 5 and Tables 6 and 7). The soils of grade1 represented an area 184702 Feddans ( 41.85 of the total studied area). The soils of this grade are deep (more than $120 \mathrm{~cm}$ in depth), the texture ranged from sandy loam to clay loam, flat, well drainage and slightly saline. 


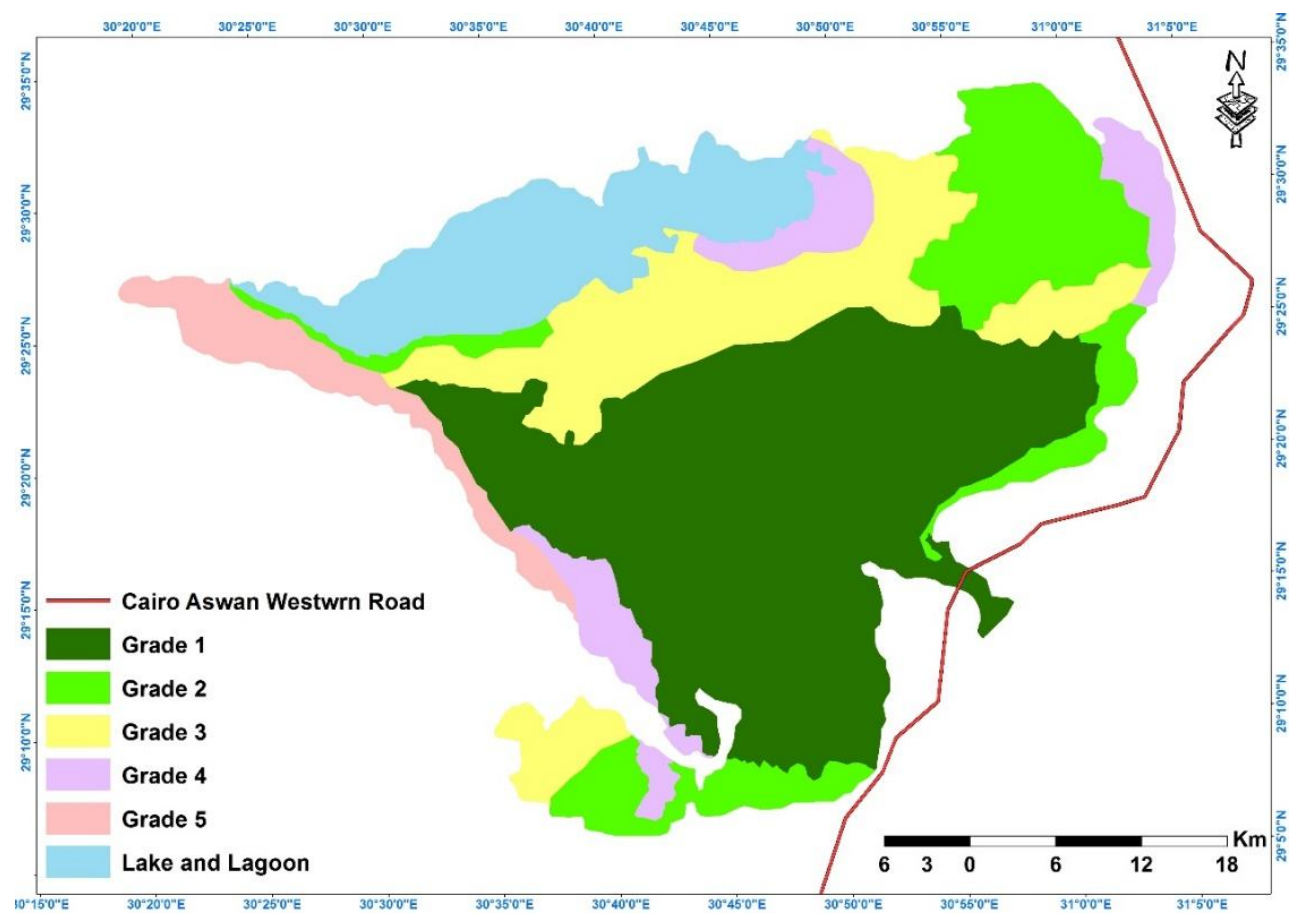

Figure 5. Land capability map of the studied area

Table 6. Areas of land capability

\begin{tabular}{|c|c|c|}
\hline Land Capability & Area (Feddans) & \% \\
\hline Grade 1 & 184702 & 41.85 \\
\hline Grade 2 & 70366 & 15.94 \\
\hline Grade 3 & 76360 & 17.30 \\
\hline Grade 4 & 30493 & 6.91 \\
\hline Grade 5 & 21450 & 4.86 \\
\hline Lake and Lagoon & 58012 & 13.14 \\
\hline Total & 441383 & 100.00 \\
\hline
\end{tabular}


Table 7. Capability index and rating of the main characteristics for mapping units.

\begin{tabular}{|c|c|c|c|c|c|c|c|c|}
\hline Mapping Unit & $\begin{array}{l}\text { Profile } \\
\text { No }\end{array}$ & $\begin{array}{c}\text { Depth } \\
\%\end{array}$ & $\begin{array}{c}\text { Texture } \\
\%\end{array}$ & $\begin{array}{c}\text { Slope } \\
\%\end{array}$ & Drainage \% & $\begin{array}{l}\text { EC } \\
\%\end{array}$ & $\begin{array}{l}{ }^{* C i} \\
\%\end{array}$ & Grade \\
\hline \multirow{5}{*}{ 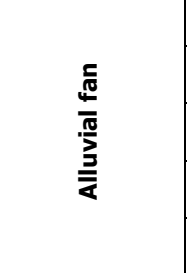 } & 3 & 100 & 70 & 100 & 100 & 80 & 56 & Grade 3 \\
\hline & 9 & 100 & 90 & 100 & 100 & 100 & 90 & Grade 1 \\
\hline & 10 & 100 & 90 & 100 & 90 & 100 & 81 & Grade 1 \\
\hline & 11 & 100 & 90 & 100 & 100 & 100 & 90 & Grade 1 \\
\hline & 12 & 100 & 95 & 100 & 100 & 100 & 95 & Grade 1 \\
\hline \multirow{4}{*}{$\begin{array}{l}\frac{5}{\pi} \\
\frac{\pi}{2} \\
\frac{\pi}{0} \\
\frac{0}{3} \\
\frac{0}{\alpha}\end{array}$} & 13 & 40 & 90 & 100 & 80 & 100 & 28.8 & Grade 4 \\
\hline & 14 & 80 & 90 & 100 & 90 & 100 & 64.8 & Grade 2 \\
\hline & 15 & 80 & 80 & 100 & 90 & 90 & 51.84 & Grade 3 \\
\hline & 16 & 80 & 80 & 100 & 90 & 100 & 57.6 & Grade 3 \\
\hline \multirow{4}{*}{ 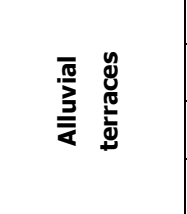 } & 1 & 80 & 80 & 100 & 90 & 60 & 34.56 & Grade 4 \\
\hline & 2 & 80 & 80 & 100 & 90 & 60 & 34.56 & Grade 4 \\
\hline & 21 & 80 & 95 & 100 & 90 & 100 & 68.4 & Grade 2 \\
\hline & 22 & 80 & 90 & 100 & 90 & 100 & 64.8 & Grade 1 \\
\hline \multirow{3}{*}{ 厄 } & 4 & 80 & 95 & 100 & 90 & 80 & 54.72 & Grade 3 \\
\hline & 23 & 80 & 90 & 100 & 90 & 100 & 64.8 & Grade 2 \\
\hline & 24 & 80 & 90 & 100 & 90 & 100 & 64.8 & Grade 2 \\
\hline \multirow{3}{*}{ 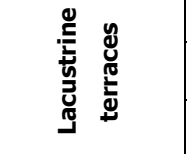 } & 5 & 80 & 80 & 100 & 90 & 90 & 51.84 & Grade 3 \\
\hline & 20 & 80 & 90 & 100 & 90 & 70 & 45.36 & Grade 3 \\
\hline & 25 & 80 & 70 & 100 & 90 & 100 & 50.4 & Grade 3 \\
\hline \multirow{3}{*}{ 竞 } & 6 & 80 & 90 & 100 & 90 & 60 & 38.88 & Grade 4 \\
\hline & 7 & 80 & 90 & 100 & 90 & 90 & 58.32 & Grade 3 \\
\hline & 8 & 80 & 95 & 100 & 90 & 100 & 68.4 & Grade 2 \\
\hline \multirow{3}{*}{ 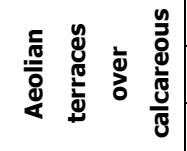 } & 17 & 40 & 80 & 90 & 80 & 80 & 18.43 & Grade 5 \\
\hline & 18 & 40 & 60 & 90 & 80 & 82 & 14.16 & Grade 5 \\
\hline & 19 & 40 & 60 & 90 & 80 & 85 & 14.68 & Grade 5 \\
\hline
\end{tabular}

$* \mathrm{Ci}=$ Capability index.

The soils of grade 2 have an area of about 70336 Feddans ( $15.94 \%$ of the total studied area). The main limiting factor for this grade is soil profile depth (moderately deep). The unit of grade 3 represented an area of about 76360 Feddans $(17.3 \%$ of the total studied area). The main limiting factors for this grade are profile depth, texture and salinity with moderate limitations. On other hand, the soils of grade 4 are representing about 30493 Feddans ( $6.91 \%$ of the total studied area). The limiting factors are profile depth and salinity with moderate to severe limitations. The soils of grade 5 have an area of about 21450 Feddans ( $4.86 \%$ of the total studied area). The main limiting factors are soil depth (shallow soils) and salinity. 


\section{5-Land suitability for certain crops:}

Land suitability for four different crops, i.e. wheat, barley, cotton and olive was tested for the soils using Arc GIS 10.4 software. The results were imported to Arc GIS to display maps. Soil characteristics of the different mapping units were matched with the crop requirements of each crop (FAO, 1976). The matching led to the current and potential suitability for each crop using the parametric approach and land index as mentioned by Sys et. al. (1993) (Table 8 and Figure 6).

Table 8. Current suitability classes and areas \% for growing crops in the studied area

\begin{tabular}{|c|c|c|c|c|c|c|}
\hline \multirow{2}{*}{ Suitability Class* } & \multicolumn{2}{|c|}{ Wheat \& Barley } & \multicolumn{2}{c|}{ Cotton } & \multicolumn{2}{c|}{ Olive } \\
\hline & Current & Potential & Current & Potential & Current & Potential \\
\hline S1 & --- & $66.87 \%$ & $41.85 \%$ & $59.23 \%$ & $41.85 \%$ & $42.40 \%$ \\
\hline S2 & $66.87 \%$ & $15.13 \%$ & $25.03 \%$ & $22.77 \%$ & $26.46 \%$ & $36.81 \%$ \\
\hline S3 & $4.22 \%$ & $4.86 \%$ & $11.00 \%$ & $4.86 \%$ & $10.91 \%$ & --- \\
\hline N1 & $15.77 \%$ & --- & $8.98 \%$ & -- & $7.65 \%$ & $7.65 \%$ \\
\hline Lake and Lagoon & $13.14 \%$ & $13.14 \%$ & $13.14 \%$ & $13.14 \%$ & $13.14 \%$ & $13.14 \%$ \\
\hline
\end{tabular}

$* * \mathrm{~S} 1=$ Highly suitable, $\quad \mathrm{S} 2=$ Moderately suitable

N1= Currently not suitable S3= Marginally suitable

\subsection{Current suitability:}

The data in Table 8 and Figure 6 show the current suitability classes for the selected studied crops. These data indicate that $41.85 \%$ El-Fayoum depression is highly suitable (S1) for cotton and olive, and $66.87 \%$ El-Fayoum depression is moderately suitable (S2) for wheat and barley.

\subsection{Potential suitability:}

From the previous discussion, the main limiting factors were soil profile depth, texture and salinity, which can be improved using good management practices such as salt leaching, use of organic matter amendments, construction of a good drainage system and follow good agriculture practices for crops. These improvements will develop the potential suitability.

The results in Table 8 and Figures 6 showed that about $59.23 \%$ of El-Fayoum depression is highly suitable (S1) for cotton. While $66.87 \%$ of El-Fayoum depression was moderately suitable (S2) for wheat and barley. 


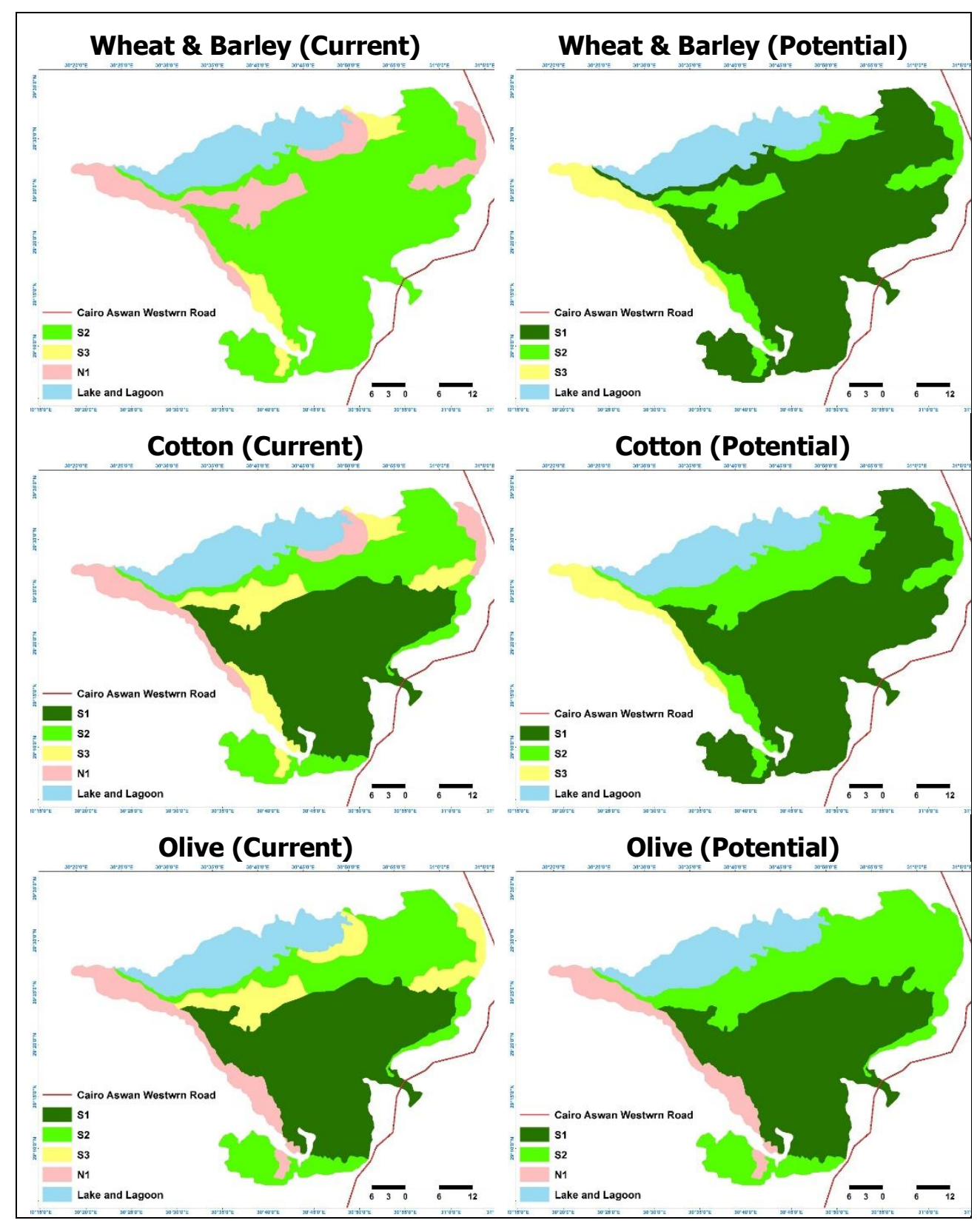

Figure 6. Current and potential land suitability for specific Crops.

\section{REFERENCES}

1. Bandyopadhyay, S., R. K. Jaiswal, V. S. Hegde and V. Jayaraman. 2009. Assessment of land suitability potentials for agriculture using a remote sensing and GIS based approach. International journal of remote sensing 30 (4): 879-895.

2. Daels, L. 1986. Remote sensing fundamentals. Gent. State Univ., Gent., ITC. J., pp.119.

3. DeVries, M. E. 1985. Use of GIS to integrate remote sensing and other natural resources data 18th International Symposium on Remote Sensing of Environment, Arbor, Michigan, International J. Remote Sensing, 31:71-90. 
4. EGSA (Egyptian Geological Survey Authority). 1988. "Egyptian General Petroleum Corporation: Geological Map of Egypt", Conoco Coral, printed in Germany by Institute fur Angewandte Geodasie, Berlin, Technische Fachhochschule Berlin, Scale 1:500000.

5. FAO. 1976. Framework for Land Evaluation. FAO Soil Bulletin, 32. Rome, Italy.

6. FAO. 2005. Fertilizer use by crop in Egypt. First version. Food and Agriculture Organization of the United Nations (FAO), Rome, Italy.

7. FAO. 2006. "Guidelines for soil description "fourth edition, FAO, Rome, ISBN 92-5105521-10.

8. Hulme, M. and R. March. 1990. Global Mean Monthly, Humidity Surfaces for 193059, 1960-89 and projected for 2020, (UNEP/GEMS/GRID, Climatic, Res. Unit Univ. of East Anglia, Norwich, England.

9. Meteorological Authority. 2017. The Normals for Egypt up to 2017. Ministry of Civil Aviation, Cairo, Egypt. Meteorological Res. Bull., 25: 50-56.

10. O'Geen A. T. and S. B. Southard. 2005. A revised Storie index model in NASIS. Soil Survey 46 (3): 98-109.

11. Rossiter, D. G., 2003. Biophysical models in land evaluation. In: Encyclopedia of Life Support Systems (EOLSS), Theme 1.5 Land Use and Land Cover (ed W.H. Verheye), Oxford: EOLSS publishers developed under the auspices of UNESCO. Article 1.5.27. pp: 1-16.

12. Said, R. 2000. The Geology of Egypt. Elsevier publishing Company, New York, U.S.A.

13. Stein, A. 1998. Integrating spatial statistics and remote sensing. INT. J., 19 (9): 1793-1814

14. Storie, R. 1978. Storie index rating. Oakland: University of California Division of Agricultural Sciences Special Publication 3203.

15. Sys, C., E. Van Ranst, J. Debavey and F. Beeranert. 1993. Land_Evaluation. Part III Crops Requirements, Ghent Univ., Ghent Belgium., The Netherlands, 190 p.

16. USDA. 2004. Soil Survey Laboratory Methods Manual, Soil Survey Investigation Report No.42: vesion 4.0 November, 2004

17. USDA. 2014. Keys to Soil Taxonomy. U.S.D.A., Soil Cons Serv. Washington.

18. Zaid, M. S.; S. M. Abd El-Rassoul and I. M. Abdalla. 2012. Soil Limitations and land capability classification of El-Fayoum governorate, J. Soil Sci. and Agric. Eng., Mansoura Univ., Vol. 3 (8): 763 - 778.

19. Zhongxin C., Sen Li, R. Jianqiang, P. Gong and M. Zhang. 2004. Monitoring and Management of Agriculture with Remote Sensing. In: Liang S. (Ed.), Advances in Land Remote Sensing. Springer, 397-421.

20. Zinck, J. A. 1988. Geomorphology and Soils. Internal Publ., ITC., Enschede, The Netherlands. 
تقييم التربة لبعض المناطق بمنخفض القيوم -مصر باستخدام تقتيات الاستشعار عن

\section{بعد ونظم المعلومات الجغرافية}

يوسف قطب الغنيمى ، محمود سليمان محمد و محمد محمد حسنى شومان

معهد بحوث الار اضى والمياه والبيئة - مركز البحوث الزراعية.

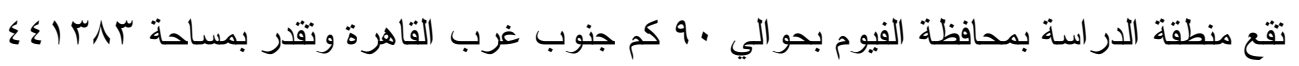
فدان ويهدف هذا البحث الي دراسة خصائص أر اضي منخفض الفيوم وتقييم كفاءتها الإنتاجية وملائمتها لاستزر اع المحاصيل الرئيسية وذلك باستخدام تقنيات الاستشعار عن البعد ونظم المعلومات الجغر افية

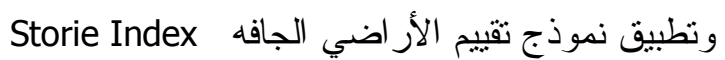

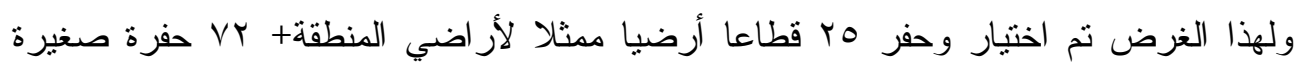
(Aguer) ، ولقد وصفت هذه القطاعات وصفا مورفولوجيا وجمعت منها عينات نتثل الاختلافات الر أسية لإجر اء للتحليلات المعلية. ولقد تم عمل خريطة فيزيوجر افية باستخدام التفسير المرئي لصورة القمر الصناعي سينتنال r مع لاهيه

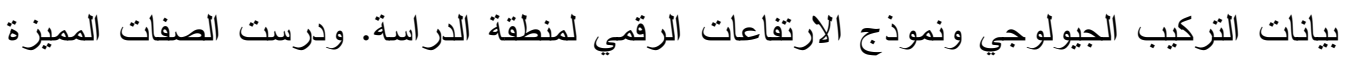
لوحدات خريطة التربة وأوضحت الدر اسة تصنيف الأر اضي الى ثلاث رتب هي and Entisols

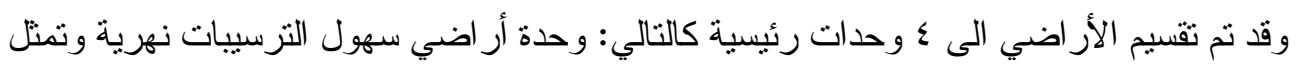

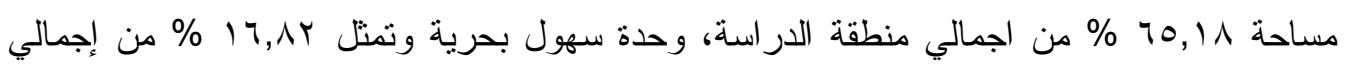

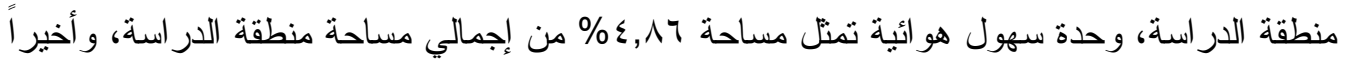

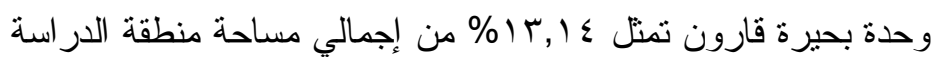
و أوضح تطبيق نموذج تقييم الار اضي الجافة Storie Index متكاملا مع نتائج نظم المطلومات

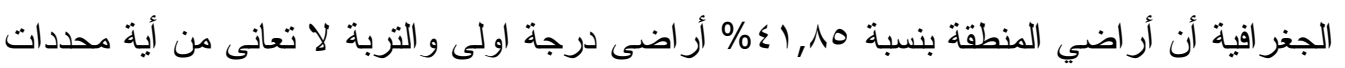

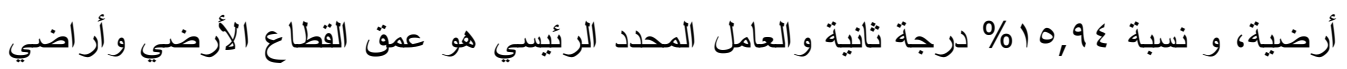

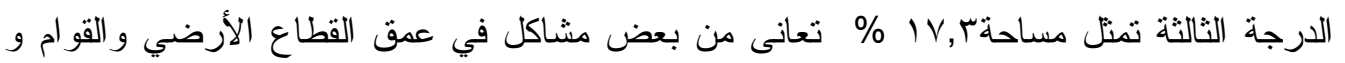

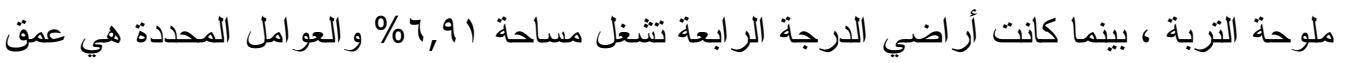

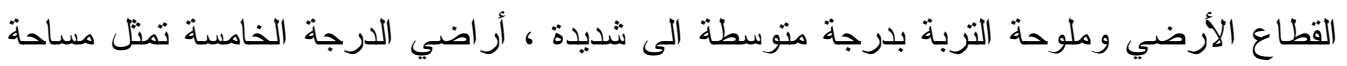

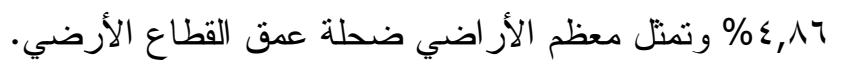
Sys et. al, وقد نم إختبار أربعة محاصيل لتقييم درجة صلاحيتها للزر اعة طبقاً لطريقة (1993) و هي و القمح و الثعبر و القطن و الزيتون، وتبين من النتائج أن الزيتون هو أفضل هذه المحاصيل حيث تجود زر اعته بدرجة أعلى من باقي المحاصيل. 
